\title{
From Fragility to Fortitude: Metamorphosis of Ma Joad
}

\author{
Dr S C Bamarani \\ Department of English, Jerusalem College of Engineering, Chennai, India
}

\begin{abstract}
The portrayal of women in literature was inevitably not balanced. From Old Testament to the present day literature the array of women characters teem with mother figures, women of power and mettle whether negative examples or positive ones. Certain characters of women exhibit considerable prominence. Women are depicted either as saints totally or as the very embodiments of temptation. Throughout American Literature, women have been depicted in many different ways. The portrayal of women in American Literature is often influenced by an author's personal experience or a frequent societal stereotype of women and their position. Steinbeck's novel, The Grapes of Wrath, Ma Joad and Rose of Sharon graphically portray the theme of women as self-sacrificing and nurturing mothers in the migrant family during the great depression. John Steinbeck has portrayed women in different avatars. The Joad wome, Rose of Sharon and Ma can rightly be said as the ideal women who are placed in the pinnacles for their self-sacrifice and endurance. Ma Joad especially stretches the radiance of love and care by helping the fellow travelers. She is crowned with her leadership roles and determination. She can be compared to the Mother earth. Steinbeck's men are outwardly poor but are exalted with glaring inner strength. The characters in the novel though ruled by self arrive at a meaningful existence as they comprehend the concept of group.
\end{abstract}

Keywords: Ma Joad, metamorphosis, Steinbeck, women

\section{Introduction}

The portrayal of women in literature was inevitably not balanced. From Old Testament to the present day literature the array of women characters teem with mother figures, women of power and mettle whether negative examples or positive ones. Certain characters of women exhibit considerable prominence. Women are depicted either as saints totally or as the very embodiments of temptation. Women feature strongly in Chaucer's earlier works, such as The Boke of the Duchess and Troilus and Criseyde.Though there are only three women on the pilgrimage described in The Canterbury Tales, they reflect the ways to achieve independence and status. Women are portrayed differently in literature depending upon the social customs and the acceptance of women in the culture of the author. The names and the environment may differ but the transformation they endure is the same.

\section{Depiction Of Ma Joad}

Initially, the novel depicted women as viewed by men, and the typical heroines were either paragons of virtue or of vice: for every Pamela Andrews or Clarissa Harlowe there was a Moll Flanders or a Fanny Hill. Novelists like, Ann Radcliffe and supremely Jane Austen depicted life and society from a woman's perspective. Thackeray's Vanity Fair is noted for the strength of its female roles. Women come into their own supremely in the novels of the Brontë sisters. In Jane Eyre, Charlotte Brontë depicts a woman who takes control of her own destiny.

The modern perception of the writers has changed considerably as they venture to explore the psychology and social roles of women with rising intensity. Thomas Hardy, D H Lawrence, E M Forster and Virginia Woolf have all made significant contributions to the perception of women in the literary standard, particularly in challenging traditional perceptions about the 'purity' of women. The influence of other European writers during the 19th century and subsequently has been significant.

The delineation of motherhood can be explored together with presentations of women as daughters or wives. Women are strong, ambitious, and independent. These are all characteristics that are associated with many of the women today. The role of women has made great tramps over past eras, as we move closer toward a state of equality. From labels such as, "Frailty, thy name is woman!" females now are productive, confident, members of society. Women now have a powerful voice in the occurrences of today.

Throughout American Literature, women have been depicted in many different ways. The portrayal of women in American Literature is often influenced by an author's personal experience or a frequent societal stereotype of women and their position. Often times, male authors interpret society's views of women in a completely different nature than a female author would. While F. Scott Fitzgerald may represent his main female character as a victim in the 1920 's, Zora Neale Hurston portrays hers as a strong, free-spirited, and 
independent woman . John Ernst Steinbeck, Jr. (February 27, 1902 - December 20, 1968) an American writer wrote the Pulitzer Prize-winning novel The Grapes of Wrath (1939) and East of Eden (1952) and the novella Of Mice and Men (1937). He wrote a total of twenty-seven books, including sixteen novels, six non-fiction books and five collections of short stories. In 1962, Steinbeck received the Nobel Prize for Literature.

Steinbeck's novel, The Grapes of Wrath, Ma Joad and Rose of Sharon graphically portray the theme of women as self-sacrificing and nurturing mothers in the migrant family during the great depression. John Steinbeck has portrayed women in different avatars . The Joad women, Rose of Sharon and Ma can rightly be said as the ideal women who are placed in the pinnacles for their self-sacrifice and endurance. Ma Joad especially stretches the radiance of love and care by helping the fellow travellers. She is crowned with her leadership roles and determination. She can be compared to the Mother earth. In 1962, Steinbeck won the Nobel Prize for literature for his "realistic and imaginative writing, combining as it does sympathetic humor and keen social perception." In his acceptance speech in Stockholm, he said:

the writer is delegated to declare and to celebrate man's proven capacity for greatness of heart and spirit-for gallantry in defeat, for courage, compassion and love. In the endless war against weakness and despair, these are the bright rally flags of hope and of emulation. I hold that a writer who does not believe in the perfectibility of man has no dedication nor any membership in literature.

The Grapes of Wrath, one of John Steinbeck's great experiments, explodes upon the American conscience in 1939, picturing the intimate reality of the Joads' suffering and the plight of the dust bowl, Oklahoma Migrants. It is a tale of oppression and endurance, Louis Kronenberger remarks the novel as "the most moving and disturbing social novel of our time" $(1)^{[1]}$.

Ma Joad, a strong character, shows positive attitude and echoes love and humanity. Her family regards her as the 'power' and she is always firm that her family should never break. It is she who gives her family a resistance against weariness. She quotes her father's words to Sairy Wilson, 'Anybody can break down. It takes a man not to'

( GW 165). ${ }^{[2]}$ She is the 'citadel of the family'.

Steinbeck pictures her as,

Her hazel eyes seemed to have experienced all possible tragedy and to mounted pain and suffering like steps into a high calm and a super understanding....... It was her habit to built up laughter out of From he position as healer, her hands had as arbiter she had $86)^{[2]}$

She gets sad when her family members stand on the road. But she comes out of it and packs the things to move to California.

Stoddard Martin has esteemed Ma Joad as "earth mother and Mother of God" (GW 72). She stands as the symbol of the humane values. She is vibrant and faces the new realities. It is she who stands near Grandpa and Grandma at the time of their death. She has to lie with the corpse of Grandma to conceal it from the cops as they cross the California border. Ma, patiently listens to the dreams of her pregnant daughter, Rose of Sharon. She gives her support when she is neglected by her husband. She gives hope to the whole family when they stand desperate. She tries her best to tame her two little kids Ruthie and Winfield.

When Al stands confused, she convinces him not to elope with the girl he loves, but to bring her and her family into a larger unit with the Joads. She gets happy when Tom Joad takes the path of Casy. She wants her son to move in order to hide himself away from the cops. She watches her son proudly, when he identifies his soul as a part of the cosmic soul. She becomes larger than life-larger because nothing can alter her humanity and strength. Her soul is a celebrated soul and her family feels her strength and majesty. She remains the priest of her vision - a vision as broad as the ocean. Her trait of simplicity and humanity, indicate her ability to lend a helping hand to those who are in need. She holds high values and strongly builds her family. Thus as a strong woman, she forces the prolonged battle for survival against adverse fortunes.

One of the central characters, Ma Joad supports the main theme of the novel - her transformation into the group. Though she couldn't attain her dream, she accepts it as an outward defeat. She stands high because of her inward victory. She is devoid of a curing nature. Steinbeck solves their problems by making them comprehend the concept of the over-soul rather than through social and legal reforms. Their journey towards California teaches them self-discovery. Steinbeck's characters uplift the readers and make them to realise the potentialities inherent in them.

Charles Child Walcutt has pointed out,

The two great elements of American naturalism spirit and fact, the demands of the heart and the demands of the mind-are Steinbeck's constant pre-occupation; they forms the poles of his thought in everyone of his novels. $(258)^{[3]}$ 
These lines underline the fact that the men of Steinbeck take a unique approach - of humanism and true love. There is a blend of goodness and innocence in her.

Emerson's thought is registered by Shanta Acharya in The Influence of Indian Thought on Ralph Waldo Emerson as

My Philosophy holds to a few laws, 1. Identity, whence comes the fact that Metaphysical faculties and facts are the transcendency of physical. $\quad 2$. Flowing or transition, or shooting the gulf, the perpetual striving to ascend to a higher platform, the same thing in new and higher forms (107) ${ }^{[4]}$

\section{Conclusion}

The poor are not aware of the holy deed they perform. But it leads them to the gradual discovery of the reality. The novelist holds the selfless poor in high esteem. James Gray stresses the dignity of beautifully brings it out in John Steinbeck,

Wide in the range of their interests, diverse in mood, passionately concerned in their sympathies, they (the novels) all celebrate the worth of man. . . .Much more clearly than in the instance of any other American writer of his time. Steinbeck consistent effort to establish the dignity of human life offers the measure of the $\operatorname{man} .(7)^{[5]}$

Steinbeck's men are outwardly poor but are exalted with glaring inner strength. The characters in the novel though ruled by self arrive at a meaningful existence as they comprehend the concept of group.

\section{References}

[1]. Kronenberger, Louis. "'Hungry Caravan", by Louis Kronenberger, The Nation, April 15, 1939, P. 440." UNZ.org. Raising American Wages, n.d. Web. 08 July 2014

[2]. Steinbeck, John. The Grapes of Wrath. New York: Viking, 1939. Print.

[3]. Walcutt, Charles Child. American Literary Naturalism, a Divided Stream. Minneapolis: U of Minnesota, 1956. Print.

[4]. Acharya, Shanta. The Influence of Indian Thought on Ralph Waldo Emerson. Lewiston, NY: Edwin Mellen, 2001. Print.

[5]. Gray, James. John Steinbeck. Minneapolis: U of Minnesota, 1971. Print. 